\title{
A Rhetoric of Cultural Contract
}

\author{
Tuyen D. Nguyen, $\mathrm{PhD}$ \\ California State University, USA \\ E-mail: trentspringfield@yahoo.com
}

Gerald Powell, PhD

The New School, USA

Received: December 17, 2011

Accepted: February 14, $2012 \quad$ Published: April 1, 2012

doi:10.5539/ijel.v2n2p3

URL: http://dx.doi.org/10.5539/ijel.v2n2p3

\begin{abstract}
This analysis utilizes Ronald Jackson's (2002) theoretical framework, Cultural Contracts of Identity, to explore the negotiation process of black identity, via Malcolm X, the central character in Spike Lee's cinematic production of $X$. Jackson's theory punctuates three socio-communicative constraints, otherwise known as cultural contracts, with which one can examine black identity - ready-to-sign, quasi-completed, and cocreated. Jackson used the term cultural contracts to refer to "the end product of identity negotiation; hence every 'signed' or agreed-upon cultural contract has a direct impact on one's identity" (p. 49). As such, the study underscores the fluid dialectical tension echoing between one's contract and one's identity. The focus here, then, is on explaining how one's identity is contingent upon the present and ensuing contracts. Select passages from the film $X$ clearly articulating a compromise in Malcolm's identity to establish a change in worldview, where possible, serve as the impetus for this analysis.
\end{abstract}

Keywords: Malcolm X, Cultural contract, Ready-to-sign contract, Quasi-completed contract, Cocreated contract

\section{Introduction}

Spike Lee produced and directed the film $X$ (1992), a docudrama chronicling spirited moments of Malcolm X's life (Malcolm X's prison years, his religious conversion and political involvement with the Nation of Islam, his personal relationship with Elijah Muhammad, his spiritual pilgrimage to Mecca, and his philosophical disposition after the pilgrimage). Most films directed by Lee encourage and attract commentary from various walks of life mainly due to the subject matter fueled by Lee's unabashed political stance. It is critical to understand Lee's vision of Malcolm's metamorphosis and the social exigencies transforming Malcolm's life, making way for a more self-reflexive human. A transformation of this caliber is grounded in a hermeneutical ethos (Watts, 2002), which implies a new way of understanding and knowing. Hermeneutical ethos addresses how a person can circumvent diametrically opposing points of view with a rhetorical sensitivity that encourages a collective communication abetting a mutual appreciation of various worldviews. Most important, a hermeneutical ethos situates itself in the field of praxis, implying that one will act judicially and prudentially with this new found knowledge (Watts, 2002). In order to secure the desired analysis - one that traces the vestiges of Malcolm's ideological growth, transformation, and maturation-it is incumbent that the analysis dislodges various discursive modes of communication emblematic of that change. Jackson's (2002) theoretical framework does just that.

\section{Theoretical Framework}

Jackson's (1999) theory consists of three components that are understood as cultural contracts: ready-to-sign, quasi-completed, and cocreated. These three components function as a net of ideological restraints underscoring degrees of assimilation. Mentioned earlier, ready-to-sign contracts require total assimilation; there is little to no space to negotiate one's identity. Quasi-completed contracts require both parties to conditionally negotiate their identities. Cocreated contracts require both parties to collectively work together; negotiating one's identity, in this regard, ensures a more prodigious relationship. The rhetorical prowess of Jackson's (2002) theory lies in the theory's descriptive and interpretive approach toward the negotiation of identity and the building process. 
Jackson (2002) submitted, "Identity negotiation refers to a conscious and mindful process of shifting one's worldview or cultural behaviors or both. During this process, cultural patterns of communicating and ways of seeing the world are at stake" (p. 49).

Negotiation is key in Jackson's (2002) description of identity. Negotiation is a term implying process of deliberation; therefore, scholars can come to an understanding that identity is a process of formation and transformation. Another dimension of Jackson's (2002) theory is a breached contract. A breached or broken contract refers to the transition from one contract to another contract. Broken contracts occur because one party refuses to assimilate to the preexisting stipulations of the contract: "As with any

negotiation, one can either abide by an existing contractual arrangement, change the terms of the contract if permissible, or choose another contract" (Jackson, 2002, p. 50).

To negotiate one's identity implies identity formation as a communicative process among two or more individuals that are driven by message exchange over a period of time. Hecht, Collier, and Ribeau (1993) suggested, "Identity is created by the individual and is cocreated [over time] as people come into contact with one another and the environment. As people align themselves with various groups, this cocreation process is negotiated" (p. 30). Over time, a social-personal identity and personal identity evolve.

Social identity is the group identity that both parties deem valuable (Jackson, 2002). It is based on pure assimilation, co-authored by the collective, forming a true assimilated sociological subject, in which each individual's identity within the group contributes to a more enigmatic identity forming in relation to the other. Hence, the partnership between assimilation and social identity aims to erase the politics of difference between "individuality" and "eccentricity." Personal identity represents the constant creation of one's being or inner core, an intersubjective project that is ontological.

James Baldwin (1974), in his seminal work If Beale Street Could Talk, described the inner conflict of personal identity and social identity. As the issue of race confronts Tish, a character in Baldwin's novel, Tish is aware of the difference between herself and others. This awareness of race makes her a stranger to herself because of the interactive tension within her inner world and the outside social world. Indeed, the persistent tension of social values and personal values germinates disharmony and variance. Although Tish is fictitious, her accounts are indicative of the balancing process of her social and personal identity. This does not assume that individuals must strive for a balance or that a balance is possible. Much of our identity is still changing. Part of negotiating one's identity is not predicting when, where, and which identity will take precedence over the other. Understanding the complexity of the identity negotiation process presupposes agency - that is, individuals have the ability to decide how much of their identity they want to negotiate and when negotiation may or may not be beneficial. Cultural contracts can be breached; it is always a person's choice to exit a contract for another.

\subsection{Quasi-Completed Cultural Contract}

Three phases of Malcolm's life that are explored through cultural contracts are his ongoings with West Indian Archie (quasi-completed cultural contract), his relationship with Elijah Muhammad (ready-to-sign cultural contract), and his relationship with the Nation of Islam as well as his post-Mecca disposition (cocreated cultural contract). It is important to keep in mind that Malcolm had many contractual relationships, but as a starting point, this analysis is an examination of Malcolm's dealings with West Indian Archie, due to that relationship's significant influence on other contracts.

After Malcolm left Boston, his travels took him to Harlem where he worked as a waiter. The pay was not good but it kept him off of the street. Still, Malcolm wanted more money, and his insatiable desires led him to West Indian Archie. West Indian Archie was a hustler. Most people thought Archie was a good person to know in the hustling world. The following dialogue speaks to this point.

$\begin{aligned} \text { Malcolm: } & \text { So I hear tell you're a good man to know. } \\ \text { Archie: } & \text { When you hear that? } \\ \text { Malcolm: } & \text { Boston, where I am from. } \\ \text { Archie: } & \text { Kiss my neck, I've never even been to Boston. } \\ \text { Malcolm: } & \text { Like the man said, a man's rep travel. } \\ \text { Archie: } & \text { Did you just con me? } \\ \text { Malcolm: } & \text { Yes, sir. } \\ \text { Archie: } & \text { Why? }\end{aligned}$


Malcolm: Because I want in. It don't take a lot to know you're already there.

Archie: I like you a lot. I like your style. You might just do, Mr. Red.

Malcolm's contract was defined according to specific stipulations/rules that he and Archie mutually agreed on. These stipulations and rules all were part of the assimilation process. The dynamics of this interactive relationship exploit several gluing components of this contract that are identified as symbolic-linguistic and symbolic-material. Malcolm's motivation for pursuing the relationship was purely symbolic-material, whereas Archie's motivation was symbolic-linguistic.

In the previous dialogue, both Malcolm and Archie carried the conviction that a man's reputation and name carried significance (Archie's more so than Malcolm's). Semantically, the significance between a symbol and what it signifies invokes a precise and exact meaning brought to life through our relationship with language; that is, our ability to draw meaning from language molds our relationship to language and the world around us. The following dialogue illustrates the significant elastic relationship between language and reality and visa versa.

Malcolm: I'm thinking about my money... Six big ones you owe me, right?

Archie: What?

Malcolm: 821. It hit, didn't it?

Archie: You didn't have 821.

Malcolm: I threw the slate at you, told you to combinate me.

Archie: You never had it.

Malcolm: I tell you, I did. Sophia was there.

Sophia: Archie, you remember don't you?

Archie: Wait, what do you expect her to say?

Sam: Don't do this.

Malcolm: All right, skip it, but you slippin'.

(Archie gives him the money.)

Sam: $\quad$ His rep is on the line. So is yours. And Red, if you're lying, you're a dead man.

Malcolm: You go and tell him that.

For African Americans, names have a sacred ontological connection with an individual's identity and being. Asante (1998) posited, "Africanity broadcasts identity and being" (p. 19). (Malcolm Little, Detroit Red, and Malcolm $X$ are significant names in terms of what they symbolically represent; However, in Lee's [1992] interpretation of Malcolm X's life, these transitions in Malcolm's life are excluded.) The name West Indian Archie is innocuous; it is simply a composite of symbols. The symbolic significance of West Indian Archie; however, suggests something quite different. West Indian Archie, a street name, signifies an individual who is malicious, dirty, street savvy, wise, and dastardly. Those who interact with West Indian Archie come to understand him through symbolic undertones. Reciprocally, that is how West Indian Archie came to see himself.

The fundamental essence of Africanity is nommo, a word that denotes the metaphysical properties existing between language and the reality it evokes for African Americans (Asante, 2002). Language provides people with mental templates that guide their suppositions about the world with which they consistently interact. Through words, we can alter reality; we can bring into being and remove from being; we can shape and change the very structure and essence of what is real. The art of speech becomes the primary mode of moving reality (McPhail, 1996). In brief, Archie's motive for creating a contract (ready-to-sign) was purely symbolic-linguistic. The preceding arguments suggest that Archie wanted to augment the symbolic value and function of his name or as described in the dialogue, his "rep."

Malcolm's motivation for establishing an alliance with Archie was symbolic-material. Malcolm wanted wealth and to acquire many of the material signs of prosperity. In addition to wealth, Malcolm gained a sum of street knowledge that would allow him to flourish as a criminal. In his ongoings with Sophia, material acquisition, especially of artifacts psychologically delineating him from blacks, was paramount. The following dialogue indicates the formation and composition of Malcolm's identity.

Malcolm: Because I want in. It don't take a lot to know you're already there. 
(Malcolm observes Archie's flamboyant suits, exquisite liquor, and Cuban cigars and the role of money).

Archie: I like you a lot. I like your style. You might just do, Mr. Red.

Malcolm was impressed by Archie's wealth and material goods. In other words, Archie represented a direct conduit to prosperity. Whereas Archie's identity is ontologically represented in the symbolic value of his name, Malcolm's identity symbolically materializes through the consumption of acquisitions. People recognize themselves in their commodities; they define themselves with the acquisition of goods and products. Following this paradigm of thinking, the motivation for signing the contract was inextricably linked to material consumption (symbolic-material). The self, then, is represented by what it consumes. As such, the examination of the quasi-completed cultural contract illustrates Malcolm and Archie's willingness to work together. Malcolm acquired the material positions, whereas Archie's street reputation was augmented. The rhetorical nuances promoting this relationship were symbolic-linguistic and symbolic-material, which was mutually beneficial for both parties. The following analysis were made concerning Malcolm and quasi-completed contracts:

- Malcolm and West Indian Archie both mutually benefited from the relationship.

- Malcolm's acquired artifacts emblematic of prosperity and wealth (symbolic material)

- West Indian Archie's street name was furthered buttressed by Malcolm's street success and association with him (symbolic linguistic)

\subsection{Ready-to-Sign Cultural Contract}

Malcolm's exodus from New York led him to the pains of the penitentiary and into the harbors of The Most Honorable Elijah Muhammad. The ready-to-sign contract is designated to this rhetorical context. A significant prerequisite to exploring Malcolm's contract is to understand the rhetorical conditions in which the contract was developed. En route to submission or the official signing of the contract, Brother Bains played an instrumental role, by way of mentorship and tutelage. Malcolm willfully submitted, not only to Allah but also to The Most Honorable One, Elijah Muhammad. Equally important, Malcolm had a clearer understanding of his identity at this point than he did in the past, so Malcolm's could look over his contract scrupulously.

Jackson (2002) noted, "[T] he nature of these contracts shifts as we mature, discover new approaches, and/or find identity shifting so exhausting that we select one contract as a means of stabilizing our lives" (p. 48). Bensen (1974) noted that a meaningful rhetorical act happens when knowledge and understanding come together. Bensen located a meaningful rhetorical act in the idea of the praxis. Weighing words carefully, the dialogue is an explicit list of do's and don'ts, which is non-negotiable, central to a ready-to-sign contract. Moreover, conjoining the dialogues purposefully argues assimilation (Malcolm's capitulation to Allah and Elijah Muhammad), essential to signing the contract.

Malcolm: I will not touch the white man's poison, his drugs, his liquor, his swine, his women.

Bains: A Muslim must be strikingly upright, an outstanding example so that those in darkness can see power of the light.

Malcolm: I will not commit adultery or fornication. I will not lie, cheat, or steal.

Bains: But the key to Islam is submission. That is why five times daily, we turn to Mecca and pray to bend our knees in submission.

Malcolm: I can't do that Brother Bains.

Bains: The lost found must bend the knees to admit their guilt. To implore Allah's forgiveness is the hardest thing on earth, the hardest and the greatest.

Malcolm: I don't know what I would say to Allah.

Bains: Have you ever been on your knees?

Malcolm: Yes, when I was... picking a lock to rob someone.

Bains: Tell Allah that.

Malcolm: You can grovel and crawl for sin, but not to save your soul.

Bains: Pick the lock, pick it.

Malcolm: I want to. God knows I want to. 
Later that night, while Malcolm slept, Elijah Muhammad appeared to Malcolm in a dream. As soon as the vision vanished, Malcolm fell on his knees submitting to Allah. Islam, translated to English, means to submit. Praying on one's knees symbolically communicates Islamic assimilation. Assimilation involves more than just a public announcement of one's newfound allegiance; it is much more complex. Assimilation unifies and create a sense of being. It is the metaphysical posture of Africology, feeling, knowing, and acting. Africology recognizes these three stances as being interrelated, not separate (Asante, 1998). These three metaphysical principles are fully engaged when Malcom signs the contract. These explanations argue plausible reasons and conditions for a ready-to-sign contract.

Prior to speaking, Malcolm prefaces his words with "All praises are due to Allah and his prophet Elijah Muhammad" or "Elijah Muhammad teaches us." Malcolm articulates himself very clearly as the messenger of Elijah Muhammad, holding Mr. Muhammad in the highest esteem. Malcolm refers to Mr. Muhammad as the "Greatest Greatness" and an infallible individual (Lee, 1992). Malcolm's first official speech under the title of National Minister takes place in Harlem. In the opening lines of his speech, he clearly delineates himself from Elijah Muhammad: "I must emphasize at the start that Elijah Muhammad is not a politician. So I'm not here this afternoon as a Republican nor as a Democrat" (Lee, 1992).

Malcolm also lectured on comparative ideology (non-violence versus self-defense). Part of his speech follows: "Elijah Muhammad is trying to teach you and I that...the white man and any other man on this earth has the God given right, the human right, and the civil right...to protect himself" (Lee, 1992). At Harvard University, Malcolm spoke about his criminal days, his involvement with illegal activities, and other illegitimate on goings that led to his newfound revelation, avowing that, had it not been for Elijah Muhammad, he would either be in prison or dead.

In the subsequent scene, Malcolm is preaching at a Mosque about black politics and Black Nationalism. According to Lee (1992) in $X$, Malcolm stated:

Mr. Muhammad said these things were gonna come to past, and now they're coming to past. I'm here to tell you about Elijah Muhammad's greatest greatness. His greatest greatness is that he has the only solution for peace in this country. The Honorable Elijah Muhammad's solution is the only solution for you and I. It's the only solution for the white man: complete separation from the black race and the white race.

The preceding excerpts are examples of the number of times Malcolm invokes Elijah Muhammad's name, clearly articulating unwavering commitment to Elijah Muhammad and the Nation of Islam.

The next set of dialogues captures a critical part of Malcolm's contract, total assimilation. The following dialogue offers substantial proof of Malcolm's assimilation and total submission to Islam and Elijah Muhammad. Malcolm's dedication was so sincere that he was called Elijah Muhammad's puppet (As Malcolm is leaving the building an irascible man yells to get Malcolm's attention)

Black Man: Yes, yes, hold on, hold on.

Malcolm: Yes, sir, it's all right, my brother. How are you?

Black Man: Can I ask you something....anything? Are you Elijah's pimp?

Malcolm: What are you saying, brother?

Black Man: His greatest greatness.

Malcolm: Just say what you're saying.

Black Man: If you don't know, man, I feel the sorriest for you.

In another scene, Betty, his wife, discusses a litigation charge brought against Mr.

Muhammad, which Malcolm suggests is founded on a bunch of visceral lies.

Malcolm: You think I'm not aware of their accusations. Brother Bains and I discussed it today.

Betty: Bains? Is he your friend?

Malcolm: What is the matter with you?

Betty: Nothing. What's the matter with you? Wake up. Are you so committed that you blinded yourself. You're so dedicated, you can't face the truth? Open your eyes. Open your eyes. You can face death 24 hours a day, but the possibility of betrayal never entered your head. 
These dialogues exude only a small indication of Malcolm's loyalty for Elijah Muhammad, Allah, and arguably those who made it possible for his conversion. In the film X, Malcolm states, "If any wrong was charged to Mr. Muhammad, I would assume the blame, even if it costs me my life, I would go to the electric chair." Malcolm proclaims in a monologue the following sentiment:

This sweet gentleman, at whose feet I kneeled, gave me the truth from his own mouth. I adored him in the sense of the Latin word adorance, which means to worship and to fear.... I pledge myself to him even if it costs me my life. (Lee, 1992)

After the Nation of Islam broke Malcolm's faith, Malcolm stated:

My faith had been shattered in a way I can never fully describe. Every second of my 12 years with Mr. Muhammad I'd been ready to die for him...I can come to [grips] with death, but not betrayal...not of the loyalty I gave to the Nation of Islam and Mr. Muhammad (Lee, 1992).

In summary of the ready-to-sign contract, the following major points are proposed:

- Rhetorical exigencies abetting exhausted contracts lead Malcolm to capitulate and resign to Allah and Elijah Muhammad.

- A sufficient condition of a ready-to-sign contract is total assimilation. Key phrases and dialogues expose Malcolm's complete adherence, allegiance, and unequivocal loyalty to Allah and Elijah Muhammad.

\subsection{Cocreated Contract}

Realizing that he had been duped by the Nation of Islam and Mr. Muhmmad, Malcolm took a pilgrimage to Mecca and experienced Islamic Brotherhood, a universal love and humanity for all. Jackson (2002) noted, "Cocreated cultural contracts are fully negotiable, with the only limits being personal preferences or requirements. This is often perceived as the optimal means of relational coordination across cultures, since the relationship is fully negotiable and open to differences" (p. 49). Malcolm's letter to Betty indicates Malcolm's open-mindedness to work with other cultures, not only in theory but in praxis:

Now you may be shocked by these words, but I've eaten from the same plate, drunk from the same glass, and prayed to the same God with Muslims whose eyes were blue, whose hair was blond, and whose skin was the whitest of the white. And we were all brothers...truly people, colors, and races believing in one God, in one humanity. In the past, I've made sweeping indictments of all white people. And these generalizations have caused injuries to some whites who didn't deserve them.

McPhail (1996) indicated that Malcolm's transformation reflects that of Peitho: "Peitho, the ancient art of rhetoric, empowers precisely because it offers the possibility of change, and the possibility to negotiate the contexts and constraints of communication between persons of reality, and of power" (p. 38). Peitho describes Malcolm's ability to transcend his partisan feelings about race and political and social issues and make favorable strides to rectify these matters through a rhetoric of cooperativeness and transcendence. If the letter is examined carefully, the logic permeating the discourse is that of a comparative rhetoric. Malcolm carefully makes use of the international and the national race relation scene to identify him and other blacks within the American racial and political struggle. By using a comparative front, Bensen (1974) reported,

Since I learned the truth in Mecca, my dearest friends have come to include all kinds-some Christians, Jews, Buddhists, Hindus, agnostics, and even atheists! I have friends who are called capitalists, socialists, communists! Some of my friends are moderates, conservatives, extremists - some are even Uncle Toms! My friends today are black, yellow, and white! (p. 5)

Terrill (2000) noted that Malcolm encouraged the members of his audience [both white and black] to abandon their limited perspective of identity, race, and politics. Malcolm invited them to refashion their identities and thus become a people, rather than that which the dominant culture had been telling them they must be.

There will always be interminable cultural and religious differences between humans. Nevertheless, having differences doesn't suggest that cultures cannot work together. McPhail (1996) noted, Peitho "enables us to move beyond argumentative [and cultural] essentialism to some common ground of understanding" (p. 35). Malcolm's discourse gives people reason to believe that a rhetoric of integration and cooperation is possible. Malcolm's embracing of the cocreated contract reveals two things:

- The cocreated contract underscores the importance of understanding one's ethnocentricity, being culturally sensitive in forming cultural criticisms, as articulated in Malcolm's letter to Betty. 
- The cocreated contract embraces the ideology of Peitho, requiring one to go beyond theoretical understanding of cultural differences, but to make concerted efforts to make amends through the active implementation of critical listening and multicultural dialogue for a human good.

\section{Final Remarks}

Spike Lee's portrayal of Malcolm's life, or any author's attempt to reconstruct a human portrait of a historical moment, is likely subject to provocation ending in varying accounts. .From a communicative standpoint, my hope is that this analysis does not incite excessive deliberation over those punctual historical moments; rather, my intention is to invite discussion concerning the efficacy of Jackson's (2002) theoretical framework to explore what numerous historians have noticed to be a change in Malcolm X's ideology and standpoint. Each cultural contract that Malcolm engages serves as a set of contextual limitations, allowing for a critical analysis of Malcolm's evolution. As such, Jackson's (2002) theory is invaluable because it makes way for a clearer understanding the dialectical tension between context and meaning, insofar as identity and negotiation of one's identity is effected by that dialectical tension.

\section{References}

Asante, K. A. (1998). The Afrocentric idea. Philadelphia: Temple University Press.

Asante, M. (2002). Intellectual dislocation: Applying analytic Afrocentricity to narratives of identity. Howard Journal of Communication, 13, 97-110. http://dx.doi.org/10.1080/106461702753555067

Baldwin, J. (1974). If Beale Street could talk. New York: The Dial Press.

Bensen, W. T. (1974). Rhetoric and autobiography: The case of Malcolm X. The Quarterly Journal of Speech, 60, 1-25. http://dx.doi.org/10.1080/00335637409383202

Hecht, L. M., Collier, M. J., \& Ribeau, S. (1993). African American communication: Ethnic identity and cultural interpretation. Communication Monographs, 66(1999), 178-197.

Jackson, R. L. (1999). The negotiation of cultural identity: Perceptions of European Americans and African Americans. Westport, CT: Blackwood.

Jackson, R. L. (2002). Exploring African American identity negotiation in the academy: Toward a transformative vision of African American communication scholarship. Howard Journal of Communications, 13, 43-57. http://dx.doi.org/10.1080/106461702753555030

Lee, S. (Producer/Director). (1992). X [ Motion picture]. Available from Forty 40 Acres and A Mule Filmworks, Inc., 124 Dekalb Avenue, Brooklyn, NY 11217.

McPhail, L. M. (1996). Zen in the art of rhetoric: An inquiry into coherence. New York: State University.

Watts, E. (2002). African American ethos and hermeneutical rhetoric: An exploration of Alain Locke's The New Negro. Quarterly Journal of Speech, 88, 1-18. 